\title{
Floral visitors of canola (Brassica napus L.) hybrids in Cerrado Mineiro region, Brazil
}

\author{
Visitantes florais em híbridos de canola \\ (Brassica napus L.) na região do Cerrado Mineiro, Brasil
}

Leandro Fuzaro $^{1 *}$ (D), Vanessa Andaló
Flávia Andrea Nery Silva' $^{1}$ (D), Fabio Janonan Malfitano Carvalho
(D),

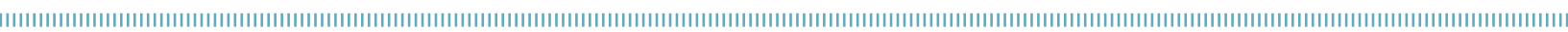

\begin{abstract}
The objective of this study was to verify floral visitors of canola in the Triângulo Mineiro region, Minas Gerais, Brazil. A completely randomized plot design with two hybrids and 10 replicates was used, totaling 20 plots. The survey of floral visitors was made during 10 days. Faunal analyses of the collected species were performed based on frequency, constancy, dominance, and diversity. A total of 2,676 individuals belonging to 13 species of bees of two families (Apidae and Halictidae) were collected. The diversity index found among hybrids was similar (1.28 in hybrid 61 and 1.50 in hybrid 433). The species Apis mellifera Linnaeus, 1758 (Hymenoptera: Apidae), Paratrigona lineata (Lepeletier, 1836) (Hymenoptera: Apidae), and Trigona spinipes (Fabricius, 1793) (Hymenoptera: Apidae) were the most abundant and constant in the crops during all the evaluated days for both hybrids. So, it is important that efforts be made to conserve natural areas close to crops in order to provide resources for the permanence of floral visitors in the area.
\end{abstract}

KEYWORDS: Apis mellifera; Apidae; faunistic index; Halictidae; native bees.
RESUMO: O objetivo deste estudo foi verificar os visitantes florais de canola na região do Triângulo Mineiro, Minas Gerais, Brasil. Utilizou-se um delineamento experimental de blocos inteiramente randomizados com dois híbridos e 10 amostras replicadas, totalizando 20 amostras. A pesquisa de visitantes florais foi feita durante 10 dias. As análises faunísticas das espécies coletadas foram realizadas com base na frequência, constância, domínio, riqueza e diversidade. Um total de 2.676 indivíduos pertencentes a 13 espécies de abelhas de duas famílias (Apidae e Halictidae) foram coletados. A riqueza das espécies encontradas entre os híbridos foi semelhante (10 espécies no híbrido 61 e 12 espécies no híbrido 433), bem como o índice de diversidade (1,28 no híbrido 61 e 1,50 no híbrido 433). A espécie Apis mellifera Linnaeus, 1758 (Hymenoptera: Apidae), Paratrigona lineata (Lepeletier, 1836) (Hymenoptera: Apidae) e Trigona spinipes (Fabricius, 1793) (Hymenoptera: Apidae) foram as mais abundantes e constantes nas culturas durante todos os dias avaliados para ambos os híbridos. Com isso, é importante que sejam feitos esforços para conservar as áreas naturais próximas às culturas, a fim de fornecer recursos para a permanência de visitantes florais na área.

PALAVRAS-CHAVE: Apis mellifera; Apidae, indices faunísticos; Halictidae; abelhas nativas. 


\section{INTRODUCTION}

Canola (Brassica napus L.) is a plant of the cruciferous family and is resultant of a genetic improvement of rapeseed (EMBRAPA, 2011). It is an autogamous plant, with an alogamy rate of more than $20 \%$, nectariferous and polliniferous, and is frequently visited by pollinating insects (TOMM et al., 2009). These are attracted mainly by the nectar produced by the floral nectaries, two in each pair of long stamens and two in the inner part of the short stamens (MUSSURY; FERNANDES, 2000). Studies demonstrate that the presence of pollinating insects, especially Apis mellifera Linnaeus, 1758 (Hymenoptera: Apidae), through its foraging behavior in flowers, can significantly increase the yield indices of this crop (DELAPLANE; MAYER, 2000; SABBAHI Et al., 2005; ABROL, 2007).

Bees are recognized as the main agents in the pollination process (KLEIN et al., 2006; OLLERTON et al., 2011), since even though varying in size, shape, and lifestyle, all bee species must visit a large number of flowers daily to suit their individual food needs, or of their offspring and the colonies (MICHENER, 2000). Visits to flowers made by other animals are occasional. The vast majority does not have flowers as their only source of food and the visits occur in isolated moments (FREITAS; PAXTON, 1998).

The presence of bees in canola flowers promotes an increase not only in the quantity of seeds produced, but also in the quality of the oil, and consequently the market value of the crop (DURÁN et al., 2010; ALI et al., 2011; BOMMARCO et al., 2012; JAUKER et al., 2012; WITTER et al., 2014). The species $A$. mellifera is the best-known pollinator of canola flowers (ADEGAS; NOGUEIRA-COUTO, 1992; SMITH, 2002; KAMLER; JAŠ, 2003; SABBAHI et al., 2005; MUNAWAR et al., 2009; DURÁN et al., 2010). However, studies performed in countries as Canada, Pakistan, Germany, and the United Kingdom observed other species of Apidae and other families as Andrenidae, Halictidae, and Megachilidae as important pollinators, such Bombus hortorum (Linnaeus, 1761), Andrena sp. Fabricius, 1775, Halictus sp. Latreille, 1804, and Osmia rufa (Linnaeus, 1758), respectively (MORANDIN et al., 2007; ALI et al., 2011; JAUKER et al., 2012; GARRATT et al., 2014).

The abundance of insects that pollinate canola flowers varies according to the region. These pollinators belong mainly to the orders Hymenoptera and Diptera (MORANDIN; WINSTON, 2005; SABBAHI et al., 2005; ALI et al., 2011; BOMMARCO et al., 2012; JAUKER et al., 2012; WITTER et al., 2014; GARRATT et al., 2014). In canola fields in Rio Grande do Sul, native insects of several groups were registered, predominantly bees (Hymenoptera), flies (Diptera), and beetles (Coleoptera) (WITTER et al., 2014).

The concern with the conservation of the bees has increased considerably due to the decline of the pollinators and, consequently, interfering in landscapes densely occupied by economic activities (KEVAN; VIANA, 2003). The factors that most contribute to the reduction of bee diversity are the habitat fragmentation, which originates from deforestation; the use of phytosanitary products in agricultural crops, and the introduction of species capable of competing with native bees, mainly for floral resources (KEARNS et al., 1998; KEVAN; VIANA, 2003).

Considering this decline in pollinator populations, the search for new bee species for pollination services in several regions of the world is increasing, since the introduction of exotic species has several restrictions (VELTHUIS; VAN DOORN, 2006). In Brazil, the efforts to use native pollinators are mainly directed to the bees Centris spp., Xylocopa spp., and many species of Meliponini. Solutions must be sought to maintain pollinators close to the rural properties, and to maintain landscapes that support pollinators and provide them a nesting site, food, and building materials for nests (WITTER; TIRELLI, 2014).

The high economic value attributed to the bees shows that pollination services in canola deserve further investigation due to the lack of knowledge about the pollination requirements of the hybrids available in Brazil. In addition, the benefit generated by the bees in canola crop can change due to local climatic conditions, which indicates the importance of understanding the possible factors that could affect the pollination process (CHAMBÓ et al., 2014).

In order to establish strategies for increasing the productivity of canola grains, it is necessary to know the regional fauna and its potential pollinators. Although there are studies in the southern region of Brazil, little is known about the diversity of these insects in regions of higher latitudes in the country, especially in the Cerrado of Minas Gerais. The objective of this study was to identify the main floral visitors of canola in the Triângulo Mineiro region located in a Cerrado area, in order to recognize their diversity.

\section{MATERIAL AND METHODS}

\section{Study sites}

The studies were conducted at the Experimental Farm of the Universidade Federal de Uberlândia, located at $19^{\circ} 05^{\prime} 48^{\prime \prime} \mathrm{S}$ and $48^{\circ} 21^{\prime} 05^{\prime \prime} \mathrm{W}$, and at an altitude of approximately $800 \mathrm{~m}$. The soil of the area is classified as dystrophic Red Latosol, A moderate, medium texture, tropical Cerrado sub-deciduous, and mild wavy relief type (EMBRAPA, 2006). The Aw climate, according to the Köppen classification, is marked by two well-defined seasons, one rainy and one dry (ROSA et al., 1991). The area contained 104 ha of preserved area, formed by complex vegetation 
that includes restricted sense Cerrado, dense Cerrado, Vereda, and Gallery forest, besides 151.72 ha with fruit and pasture (NETO, 2008).

A completely randomized experimental design with two hybrids and 10 replications was used, totaling 20 plots. Each plot consisted of six planting lines with four meters in length, $0.20 \mathrm{~m}$ spacing between rows, and a density of $18 \mathrm{~m}^{-1}$ seeds. The plots were separated by $0.5 \mathrm{~m}$, totaling an experimental area of $121 \mathrm{~m}^{2}$, so the flowers could form a compact area to cause attractiveness to the insects. The experiment was established on April 2, 2016, with both hybrids flowering after 55 days and presenting senescence after 97 days.

The hybrids used in this experiment were Hyola 61 and Hyola 433. The hybrid Hyola 61 has polygenic resistance to Phoma lingam Tode ex. Shaw. Desm., known as blackleg, and excellent performance both under water deficiency and severe cold. This hybrid has medium cycle characteristics of 123 to 155 days from emergence to maturation and presents great stability of yield when cultivated under varied conditions. Hyola 433 is a short-cycle hybrid suitable for highly fertile soils (TOMM et al., 2009).

To control insect pests, mainly aphids of the species Lipaphis pseudobrassicae Davis, 1914 (Hemiptera: Aphididae), and Myzus persicae Sulzer, 1776 (Hemiptera: Aphididae), two applications of Decis $25 \mathrm{EC}^{\circ}$ were performed, on June 4 and 15, and one application of Acephate Nortox on June 26, prior to the beginning of the evaluations.

The experiment was conducted without an irrigation system. The irrigation was performed manually, with a volume of $20 \mathrm{~mm}$ per plot, once a week, until the complete establishment of the plants. The management of weeds was done by manual weeding throughout the conduction of the experiment.

\section{Sampling visitors}

The survey of floral visitors was carried out in May and June of 2016, periods in which the averages of temperature and relative humidity of the air were $21.4^{\circ} \mathrm{C}$ and $74.8 \%$ respectively, according to National Meteorological Institute (INMET).

The samples were collected during 10 days of evaluation, and the insects sighted in the plots were collected to posterior identification. The evaluations were performed on 2 plots per day, one for each hybrid. After 10 days all plots were observed (since there were 10 replications per hybrid).

The same plot of each hybrid was evaluated along the day, to make it possible the comparison of the data on insect visitors in different times, so each plot was evaluated seven times in at the same day. Each observation lasted 20 min per plot adopting intervals of $20 \mathrm{~min}$ to start the next hour of evaluation, so in 1 hour two plots were evaluated, one for each hybrid. The evaluations occurred starting at 7:00 a.m. until 10:00 a.m. and from 1:00 p.m. to 3:00 p.m.
The collections were performed in different days, so the presence of insects could vary, however both hybrids were evaluated at the same day to become possible a comparison between them.

The specimens were collected with entomological net and stored in $100 \mathrm{~mL}$ plastic bottles with a screw cap. The collected species were recorded and only released after the daily evaluations. This procedure was adopted mainly for $A$. mellifera. The individuals not identified in the field were sacrificed with ethyl acetate and individualized for later identification in the laboratory by a specialist. Afterwards, the bees were kept in entomological drawers (TAURA; LAROCA, 2001) at Universidade de Uberlândia.

\section{Faunistic indexes}

Faunal analyses of the collected species were performed based on frequency, constancy, dominance, and diversity indexes.

Constancy, frequency, and dominance were calculated using the equations proposed by SILVEIRA-NETO et al. (1976). Frequency represents the participation of individuals of a species in relation to the total of individuals collected and was obtained by the formula $\mathrm{F}=(\mathrm{n} / \mathrm{N}) \times 100$, where $\mathrm{F}=$ frequency percentage; $\mathrm{n}=$ number of individuals of the species; $\mathrm{N}=$ total number of individuals obtained in each collection.

Constancy was obtained by the occurrence of the species in the collections by the formula $\mathrm{C}=(\mathrm{p} / \mathrm{N}) \times 100$, where $\mathrm{C}=$ percentage of constancy, $\mathrm{p}=$ number of samples contain ing the species, $\mathrm{N}=$ total number of samples.

The species were then classified into categories according to the BODENHEIMER classification (1955) in: constant species (W) - present in more than $50 \%$ of the collections; accessory species $(\mathrm{Y})$ - present in $25-50 \%$ collections; accidental species $(\mathrm{Z})$ - present in less than $25 \%$ of the collections.

A species is considered dominant when it has a frequency higher than $1 / S$, where $S$ is the total number of species in the community. The diversity index was measured by the index $\alpha$, based on MARGALEF (1972), which is the ratio between the number of species $(S)$ and the number of individuals in a community $(\mathrm{N})$.

\section{Data analysis}

The Anderson-Darling normality test $(\mathrm{AD})$ was applied with a significance of $5 \%$, so an $\mathrm{AD}$ with value of $\mathrm{p}>0.05$ has normal distribution. The Levene test was applied to homoscedasticity, considering 5\% reference to significance. The normal distribution with the "Z" test was applied for two independent means and the two-proportion test, adopting alpha rejection level of 0.05 and the critical value of "Z" of alpha 1.96. The analyses were done in program $R$. 


\section{RESULTS}

\section{Sampling visitors}

In relation to the insect sampling in the two canola hybrids, 2,676 individuals belonging to 13 bee species of two families (Apidae and Halictidae) were collected. The number of individuals collected in the H61 hybrid was lower than $\mathrm{H} 433$, but there was no significant difference among the dominant species, except for Paratrigona lineata (Lepeletier, 1836) (Hymenoptera: Apidae), found more frequently in $\mathrm{H} 433$ (39.58\%) than in H61 (35.20\%). This difference could be caused mainly because $\mathrm{H} 433$, characterized by being a fast-cycle hybrid, had a higher number of flowering plants and, consequently, a greater number of flowers and floral resources available to the insects compared to H61, which is an intermediate cycle hybrid (Table 1).

The species Tetragona clavipes (Fabricius, 1804) (Hymenoptera: Apidae), Exomalopsis fulvofasciata (Smith, 1879) (Hymenoptera: Apidae), and Augochloropsis sp. 3 (Hymenoptera: Halictidae) were not found in H61, and Augochloropsis sp. 1 were not found in H433. The diversity indexes between hybrids were similar (1.28 in H61 and 1.50 in H433). Values between 1.5 and 3.5 (Table 1) are considered normal according to MARGALEF (1972). Values below 1.5 could be a result of the predominance of some taxonomic groups to the detriment of the majority, while values over 5.0 denote levels above normal (BEGON et al., 1996).
The subfamily Halictinae, a group of generalist pollinators (EICKWORT, 1969), presented 5 species for both hybrids. However, the constancy of the species sampled was considered accidental $(Z)$, occurring in less than $25 \%$ of the collections in both hybrids, except for Augochlora sp. 2, a species considered accessory $(\mathrm{Y})$ according to the classification of BODENHEIMER (1955), with a collection frequency between 25 and $50 \%$ (Table 1).

The subfamily Apinae, characterized as being a species of social bee and with a structure to transport pollen (corbicula), was the most representative with $95.98 \%(\mathrm{n}=1,099)$ and $96.8 \%(\mathrm{n}=1,482)$ of the total collections in hybrids H61 e H433, respectively. Apis mellifera, P. lineata, and Trigona spinipes (Fabricius, 1793) (Hymenoptera: Apidae) were the most constant and dominant species in relation to the others (Table 1).

Six species of the subfamily Halictinae were collected all belonging to the Augochiorini tribe (Table 1). Among the bees of the Augochiorini tribe, it was obtained two species belonging to the genus Augochlora and four to the genus Augochloropsis, bees of metallic color, often in shades of green. This group of bees is considered very diverse, with a large number of species in Brazil. In the present study, species of the genus Augochlora and Augochloropsis were considered accidental species in canola flowers, with a frequency of less than $0.5 \%$, except for Augochlora sp. 2 which was considered an accessory species in both evaluated hybrids (Table 1).

Table 1. Faunistic analysis of the collected floral visitors in Hyola 61 and Hyola 433 hybrids, Uberlândia, Minas Gerais, 2016.

\begin{tabular}{|c|c|c|c|c|c|c|c|c|c|c|c|}
\hline \multirow{2}{*}{ Family } & \multirow{2}{*}{ Subfamily } & \multirow{2}{*}{ Tribe } & \multirow{2}{*}{ Species } & \multicolumn{4}{|c|}{ Hyola 61} & \multicolumn{4}{|c|}{ Hyola 433} \\
\hline & & & & $\mathbf{N}$ & $F(\%)$ & c (\%) & D & $\mathbf{N}$ & F (\%) & C (\%) & D \\
\hline \multirow[t]{7}{*}{ Apidae } & Apinae & Apini & Apis mellifera & 464 & 40.52 & w & D & 581 & 37.95 & w & $\mathrm{D}$ \\
\hline & & Meliponini & Paratrigona lineata & 403 & 35.20 & w & D & 606 & 39.58 & w & D \\
\hline & & & Trigona spinipes & 232 & 20.26 & W & D & 293 & 19.14 & w & D \\
\hline & & & Tetragona clavipes & 0 & 0.00 & - & - & 2 & 0.13 & z & $\mathrm{N}$ \\
\hline & Xylocopinae & Exomalopsini & Exomalopsis analis & 14 & 1.22 & Y & $\mathrm{N}$ & 16 & 1.05 & Y & $\mathrm{N}$ \\
\hline & & & Exomalopsis fulvofasciata & 0 & 0.00 & - & - & 1 & 0.07 & z & $\mathrm{N}$ \\
\hline & & & Exomalopsis auropilosa & 4 & 0.35 & z & $\mathrm{N}$ & 4 & 0.26 & z & $\mathrm{N}$ \\
\hline \multirow[t]{10}{*}{ Halictidae } & Halictinae & Augochiorini & Augochlora sp. 1 & 5 & 0.44 & z & $\mathrm{N}$ & 3 & 0.20 & z & $\mathrm{N}$ \\
\hline & & & Augochlora sp. 2 & 18 & 1.57 & Y & $\mathrm{N}$ & 21 & 1.37 & Y & $\mathrm{N}$ \\
\hline & & & Augochloropsis sp. 1 & 1 & 0.09 & z & $\mathrm{N}$ & 0 & 0.00 & - & - \\
\hline & & & Augochloropsis sp. 2 & 1 & 0.09 & z & $\mathrm{N}$ & 1 & 0.07 & z & $\mathrm{N}$ \\
\hline & & & Augochloropsis sp. 3 & 0 & 0.00 & - & - & 1 & 0.07 & z & $\mathrm{N}$ \\
\hline & & & Augochloropsis sp. 4 & 3 & 0.26 & z & $\mathrm{N}$ & 2 & 0.13 & z & $\mathrm{N}$ \\
\hline & & & TOTAL & 1,145 & 100 & & & 1,531 & 100 & & \\
\hline & & & S & 10 & & & & 12 & & & \\
\hline & & & ID & 1.28 & & & & 1.50 & & & \\
\hline & & & $1 / \mathrm{S}$ & 10.00 & & & & 8.33 & & & \\
\hline
\end{tabular}

$\mathrm{N}$ : number of captured individuals; F: frequency (\%); S: number of species; ID: diversity index; C: constancy (W: constant, Y: accessory, Z: accidental); D: Dominance (D: Dominant, N: Non-dominant). 


\section{Frequency of floral visitors per day and per hour}

The species A. mellifera, P. lineata, and T. spinipes were predominantly the most abundant and frequent species in the canola crop during the 10 days of evaluation. In H61, A. mellifera presented the largest number of individuals collected $(\mathrm{n}=464)$, being more frequent in six days of evaluation (Table 2). For H433, P. lineata and A. mellifera were the most frequent during the days and presented the largest number of individuals collected, $\mathrm{n}=606$ and $\mathrm{n}=581$, respectively, with no significant difference between them. The species T. spinipes presented similar frequency in the two hybrids ( $\mathrm{H} 61=20.26 \%$ and $\mathrm{H} 433=19.14 \%)$. The other species presented frequencies lower than $6.9 \%$ per day and represented $4.45 \%$ of the collections in $\mathrm{H} 61$ and 3.32\% in H433 (Table 2).

In both hybrids, forage activity was observed at 7:00 am, but with a reduced number of individuals. The activity began to intensify and increase from 8:00 am, culminating in a peak (maximum foraging activity) around 9:00 am (H61: $\mathrm{n}=280 ; \mathrm{H} 433: \mathrm{n}=337$ ), with a slight decrease at 10:00 am. During the morning period, $A$. mellifera was the most abundant species in the crop, with a frequency higher than $50.3 \%$ at all times (Table 3 and Fig. 1). In the afternoon period,

Table 2. Total floral visitors collected in the flowers of canola (Brassica napus) in 10 days of evaluation, Uberlândia, Minas Gerais, 2016.

\begin{tabular}{|c|c|c|c|c|c|c|c|c|c|c|c|c|c|c|c|c|}
\hline \multirow{3}{*}{ Day } & \multicolumn{8}{|c|}{ Hybrid Hyola 61} & \multicolumn{8}{|c|}{ Hybrid Hyola 433} \\
\hline & \multicolumn{2}{|c|}{ A. mellifera } & \multicolumn{2}{|c|}{ P. lineata } & \multicolumn{2}{|c|}{ T. spinipes } & \multicolumn{2}{|c|}{ Other species } & \multicolumn{2}{|c|}{ A. mellifera } & \multicolumn{2}{|c|}{ P. lineata } & \multicolumn{2}{|c|}{ T. spinipes } & \multicolumn{2}{|c|}{ Other species } \\
\hline & $\mathrm{N}$ & F (\%) & $\mathrm{N}$ & $F(\%)$ & $\mathrm{N}$ & F (\%) & $\mathrm{N}$ & F (\%) & $\mathrm{N}$ & F (\%) & $\mathrm{N}$ & F (\%) & $\mathrm{N}$ & $F(\%)$ & $\mathrm{N}$ & F (\%) \\
\hline 1 & 50 & 51.02 & 19 & 19.39 & 22 & 22.45 & 7 & 7.14 & 73 & 57.94 & 19 & 15.08 & 26 & 20.63 & 8 & 6.35 \\
\hline 2 & 65 & 56.03 & 24 & 20.69 & 19 & 16.38 & 8 & 6.90 & 74 & 51.39 & 46 & 31.94 & 17 & 11.81 & 7 & 4.86 \\
\hline 3 & 61 & 50.41 & 32 & 26.45 & 23 & 19.01 & 5 & 4.13 & 59 & 40.14 & 43 & 29.25 & 42 & 28.57 & 3 & 2.04 \\
\hline 4 & 48 & 32.21 & 63 & 42.28 & 33 & 22.15 & 5 & 3.36 & 69 & 38.33 & 74 & 41.11 & 31 & 11.67 & 6 & 3.33 \\
\hline 5 & 38 & 41.76 & 16 & 17.58 & 34 & 37.36 & 3 & 3.30 & 65 & 44.83 & 29 & 20.00 & 45 & 31.03 & 6 & 4.14 \\
\hline 6 & 31 & 27.68 & 40 & 35.71 & 37 & 33.04 & 4 & 3.57 & 48 & 28.92 & 68 & 40.96 & 42 & 25.30 & 8 & 4.82 \\
\hline 7 & 22 & 20.95 & 59 & 56.19 & 17 & 16.19 & 7 & 6.67 & 36 & 19.35 & 103 & 55.38 & 39 & 20.97 & 8 & 4.30 \\
\hline 8 & 43 & 34.96 & 39 & 31.71 & 33 & 26.83 & 8 & 6.50 & 62 & 33.88 & 79 & 43.17 & 35 & 19.13 & 7 & 3.83 \\
\hline 9 & 52 & 54.74 & 35 & 36.84 & 6 & 6.32 & 2 & 2.11 & 50 & 39.37 & 65 & 51.18 & 8 & 6.30 & 4 & 3.15 \\
\hline 10 & 54 & 38.57 & 76 & 54.29 & 8 & 5.71 & 2 & 1.43 & 45 & 33.09 & 80 & 58.82 & 8 & 5.88 & 3 & 2.21 \\
\hline Total & $464 a$ & & $403 \mathrm{~b}$ & & $232 c$ & & $51 d$ & & $581 a$ & & $606 a$ & & $293 b$ & & $60 c$ & \\
\hline
\end{tabular}

$\mathrm{N}$ : number of captured individuals; F: frequency (\%). Apis mellifera, Paratrigona lineata, Trigona spinipes.

*Lowercase letters distinguish significant differences between the totals of individuals collected for each species for each hybrid. The binomial test was used with significance of 0.95 .

Table 3. Number of floral visitors collected per hour in canola flowers, Brassica napus, Uberlândia, Minas Gerais, 2016.

\begin{tabular}{|c|c|c|c|c|c|c|c|c|}
\hline \multirow{2}{*}{ Time } & \multicolumn{4}{|c|}{$\begin{array}{c}\text { Hybrid Hyola } 61 \\
\text { (Number of individuals) }\end{array}$} & \multicolumn{4}{|c|}{$\begin{array}{c}\text { Hybrid Hyola } 433 \\
\text { (Number of individuals) }\end{array}$} \\
\hline & $\begin{array}{l}\text { Apis } \\
\text { mellifera }\end{array}$ & $\begin{array}{l}\text { Paratrigona } \\
\text { lineata }\end{array}$ & $\begin{array}{l}\text { Trigona } \\
\text { spinipes }\end{array}$ & $\begin{array}{l}\text { Other } \\
\text { species }\end{array}$ & $\begin{array}{l}\text { Apis } \\
\text { mellifera }\end{array}$ & $\begin{array}{l}\text { Paratrigona } \\
\text { lineata }\end{array}$ & $\begin{array}{l}\text { Trigona } \\
\text { spinipes }\end{array}$ & $\begin{array}{l}\text { Other } \\
\text { species }\end{array}$ \\
\hline o7hoo & $5 a$ & $1 \mathrm{~b}$ & $2 a b$ & $\mathrm{OC}$ & $19 a$ & $1 \mathrm{~b}$ & $5 b$ & $\mathrm{OC}$ \\
\hline o8h00 & $82 a$ & $19 \mathrm{~b}$ & $33 c$ & $4 d$ & $79 a$ & $14 b$ & $57 c$ & $7 \mathrm{~b}$ \\
\hline 09hoo & $167 a$ & $34 b$ & $79 c$ & $9 \mathrm{~d}$ & $199 a$ & $41 b$ & $97 \mathrm{c}$ & $9 d$ \\
\hline $10 h 00$ & $124 a$ & $49 \mathrm{~b}$ & $66 \mathrm{~b}$ & $16 \mathrm{c}$ & $161 \mathrm{a}$ & $77 \mathrm{~b}$ & $74 b$ & $16 \mathrm{c}$ \\
\hline $13 \mathrm{hOO}$ & $45 a$ & $124 b$ & $30 a$ & $8 c$ & $52 \mathrm{a}$ & $203 b$ & $25 c$ & $10 \mathrm{~d}$ \\
\hline $14 \mathrm{hOO}$ & $20 a$ & $101 \mathrm{~b}$ & $16 a$ & $10 \mathrm{c}$ & $38 a$ & $161 \mathrm{~b}$ & $21 \mathrm{c}$ & $14 \mathrm{c}$ \\
\hline $15 \mathrm{hoO}$ & $21 a$ & $75 b$ & $6 c$ & $4 c$ & $33 a$ & $109 \mathrm{~b}$ & $14 c$ & $4 d$ \\
\hline
\end{tabular}

*Totals followed by the same letter in the lines do not differ from each other by the binomial test (significance of 0.95) for the number of individuals collected per species in each hour. 
the total number of individuals continued to decrease until 3:00 p.m. (H61: $\mathrm{n}=102 ; \mathrm{H} 433: \mathrm{n}=156)$. In this period, P. lineata was the most abundant species, with a frequency above 59.9\% between 1:00 p.m. and 3:00 p.m., the last collection time (Table 3 and Fig. 1).

\section{DISCUSSION}

The three species of Exomalopsis found in canola fields (E. analis, E. fulvofasciata, and E. auropilosa) occur in most parts of the Brazilian territory (SANTOS et al., 2014), even in open areas, with little forest cover (GLAGLIANONE; CAMPOS, 2015). They are considered small bees, up to $8 \mathrm{~mm}$ in length (MICHENER, 2000). In the present work, it was verified that $E$. analis was considered an accessory species $(\mathrm{Y})$ in both hybrids, being present in $70 \%$ of the days of collection (Table 1). This indicates that these bees can survive in agricultural fields, and their nests may be constructed in the ground in the middle of the plantation or in marginal areas. Therefore, conserving the soil in these areas and avoiding the overuse of plant protection products are important measures to maintain the populations of these bees (GLAGLIANONE; CAMPOS, 2015).

After detecting the effective pollinating bees in a crop, one should consider how to increase the frequency of visits of these species, aiming to elevate the productivity through the presence of bees. The knowledge of the species biology is also necessary in order to improve the techniques that favor the presence of bees in the crops (SANTOS et al., 2014). One of the main aspects of the species to be observed is the nesting habit, which could influence their management in the areas (GARÓFALO et al., 2012).

For most species that nest in the soil, such as $E$. analis and $P$. lineata, management techniques are still scarce (IMPERATRIZ-FONSECA et al., 2006). However, A. mellifera, besides its wide distribution, is recognized for being a versatile species and of easy handling (KLEIN et al., 2006). Studies with the objective of investigating their influence on canola production have already been conducted in several parts of the world. In Canada, SABBAHI et al. (2005) found a $46 \%$ increase in productivity with an introduction of three colonies of $A$. mellifera per hectare.

In Rio Grande do Sul, studies with Hyola 432 hybrid showed that $A$. mellifera can increase yield up to $70 \%$ (ROSA et al., 2011), proving to be an efficient pollinator of this crop. However, as an exotic species, it can change the structure of interactions between native bees and plants in the natural community (SANTOS et al., 2012; SILVEIRA et al., 2006).

Considering the use of native bee species as potential pollinators of canola is not only beneficial for crop productivity, but also helps to promote the conservation of native pollinator populations (BLOCHTEIN et al., 2015).

The management of native bees should be conducted with caution, as they are in an accelerated disappearance process (LOPES et al., 2005). It is necessary to perform responsible management in which there is a balance between the commercial interests and the conservation of the native bees (DEL SARTO et al., 2005), preventing the aggravation of this situation.

The species $A$. mellifera is the main species used for the pollination of agricultural crops in the world and was reported as the main pollinator of canola in previous studies (ADEGAS; NOGUEIRA-COUTO, 1992; SMITH, 2002; KAMLER; JAŠ, 2003; MUNAWAR et al., 2009). In the state of Rio Grande do Sul, Brazil, most pollination of canola flowers is carried out by this insect, since this is the most abundant species among flowers (ROSA et al., 2011; WITTER et al., 2014; HALINSKI et al., 2015). In this study, this species was dominant and constant in both hybrids, but presented a higher frequency in H61 (40.52\%). In H433, the species had the second highest frequency among species (37.95\%), with P. lineata being the most frequent in the crop (39.58\%) (Table 1).

\section{B}

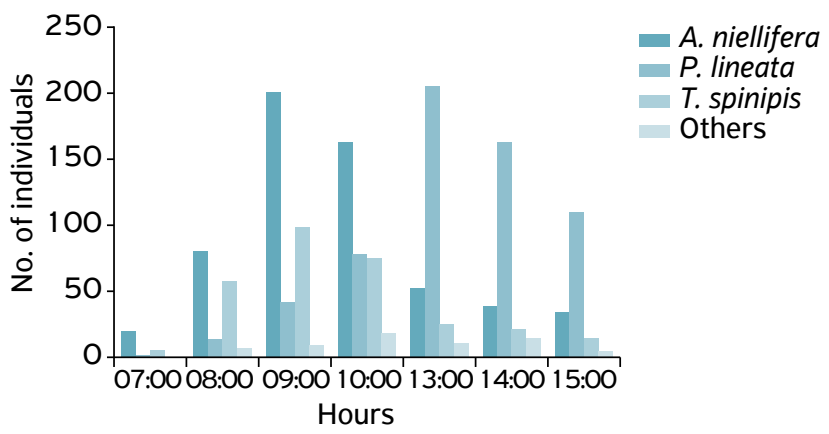

Figure 1. Floral visitors collected considering the evaluation time (from 7:00 a.m. to 3:00 p.m.) in canola, Brassica napus, Uberlândia, Minas Gerais, 2016. Hybrids (A) Hyola 61 and (B) Hyola 433. 
Paratrigona lineata is a stingless bee species and therefore has management advantages over other species, such as being easily domesticated, having highly populated and perennial nests, utilizing worker recruitment strategies, and continuous foraging (HEARD, 1999). The species presented abundance close to A. mellifera. Besides that, it remained for longer periods in the flowers than the other species.

Trigona spinipes, an abundant species in the Brazilian Cerrado (SANTOS et al., 2004), was the third most frequent and dominant species in the crop (Table 1). According to ALMEIDA; LAROCA (1988), this species has some characteristics that favor its abundance in several habitats, such as the aggressive forager bees, nests constructed in places of difficult access, generalist collecting habits, and populous colonies. However, it is considered a pest in several crops because of the damages caused during the collection of plant tissue used in the construction of the nests (FADINI; SANTA-CECÍLIA, 2000; VIEIRA et al., 2007). Despite being observed collecting plant tissue in vegetative parts of the canola, this species was present in floral buds, but not observed perforating these structures.

In general, the high frequencies found for $A$. mellifera and T. spinipes were already expected, since both are the most abundant species in the Brazilian Cerrado (CARVALHO; BEGO, 1995). These species of bees are characterized by presenting very populous colonies containing 5,000 to 180,000 individuals (MARTINS, 1994). Thus, they present high recruitment potential for foraging, contributing with a high number of bees visiting the flowers (BOREHAM; ROUBIK, 1987). However, P. lineata, which was present with low frequencies and was not considered an effective pollinator in previous studies implanted in the Cerrado region with different crops, such as tomato, Lycopersicon esculentum (SANTOS et al., 2014) and cotton, Gossypium hirsutum L. r. latifolium (PIRES et al., 2006), was present with high frequency.

Canola flowers secrete large amounts of nectar that is very attractive to $A$. mellifera and other pollinating insects (DELAPLANE; MAYER, 2000). In this study, floral visitors showed a similar pollen and nectar collection behavior, preferentially collecting nectar in the morning and pollen in the afternoon, except for $T$. spinipes, which collected only plant fibers from the stem in the afternoon (Table 3). The preference for collecting nectar in the morning may be related to the greater availability of this resource after the opening of the flowers at that time.

The physical characteristics and physiological limitations of floral visitors can generate patterns of visitation influenced by other factors such as luminosity and temperature (RAMALHO et al., 1991). Apis mellifera was the main species collected at 7:00 a.m., with lower temperatures.
This result may have occurred due to the ability to maintain high body temperature, which guarantees them access to the flowers very early, as well as promoting a great advantage in the competition for floral resources in relation to native bees (PIRANI; CORTOPASSI-LAURINO, 1993). In the earlier sampling times, the frequencies of the native species were relatively low.

In addition to the physiological constraints, these patterns of visitation can also be shaped by competition. Apis mellifera, besides being abundant, presents a greater competitive capacity in the exploration of resources (WILMS et al., 1996), and can influence the visitation of other species. Paratrigona lineata, being a small species in relation to the others and not very aggressive with the other species, did not influence the visitation of other bees.

In the present study, there was a low temporal overlap of niches between the two main species visiting the crop, with A. mellifera being more abundant in the morning (H61: $\mathrm{n}=$ 378, H433: $\mathrm{n}=458)$ and $P$. lineata in the afternoon $(\mathrm{H} 61$ : $\mathrm{n}=300 ; \mathrm{H} 433: \mathrm{n}=473$ ). However, T. spinipes competed with A. mellifera because it collected floral resources in the morning, presenting similar frequency peaks at similar times, and displaying some aggressiveness in relation to resource exploration (Table 3 and Fig. 1).

The alternating temporal habits between $A$. mellifera and $P$. lineata can be considered advantageous, since in both periods (morning and afternoon) the flowers were densely attended by insects, presenting high rates of daily. In addition, the crop was also considered attractive to local insects, as floral resources were offered to be explored for much of the day.

\section{CONCLUSION}

The main species visiting canola crops in Cerrado Mineiro were A. mellifera, P. lineata, and T. spinipes, in both evaluated hybrids. Apis mellifera and T. spinipes were found more frequently in the morning and $P$. lineata in the afternoon. The evaluated hybrids differed mainly in relation to the number of individuals collected, with $\mathrm{H} 433$ being considered more attractive than H61 during the evaluated period.

\section{FUNDING}

The authors would like to thank the Minas Gerais State Research Foundation (FAPEMIG). This study was financed in part by the Coordenação de Aperfeiçoamento de Pessoal de Nível Superior - Brasil (CAPES) Finance Code 001. 

REFERENCES

ABROL, D.P. Honeybees and rapeseed: a pollinator-plant interaction. Advance in Botanical Research, v.45, p.337-367, 2007. http:// dx.doi.org/10.1016/S0065-2296(07)45012-1

ADEGAS, J.E.B.; NOGUEIRA-COUTO, R.H. Entomophilous pollination in rape (Brassica napus L. var oleifera) in Brazil. Apidologie, v.23, n.23, p.203-209, 1992. https://doi.org/10.1051/ apido: 19920302

ALI, M.; SAEED, S.; SAJJAD, A.; WHITTINGTON, A. In search of the best pollinators for canola (Brassica napus L.) production in Pakistan. Applied Entomology and Zoology, v.46, n.3, p.353361, 201 1. http://dx.doi.org/10.1007/s13355-011-0051-0

ALMEIDA, M.C.; LAROCA, S. Trigona spinipes (Apidae, Meliponinae): taxonomia, bionomia e relação tróficas em áreas restritas. Acta Biológica Paranaense, v.17, n. 1/4, p.67-108, 1988. http:// dx.doi.org/10.5380/abpr.v17i0.803

BEGON, M.; HAPER, J.L.; TOWNSEND, C.R. Ecology: individuals, populations and communities, 3. ed. Oxford: Blackwell Science, 1996. 1068p.

BLOCHTEIN, B.; WITTER, S.; HALINSKI, R. Plano de manejo para polinização da cultura da canola: conservação e manejo de polinizadores para agricultura sustentável, através de uma abordagem ecossistêmica. Rio de Janeiro: Funbio, 2015. 44p.

BODENHEIMER, F.S. Precisd'écologie animal. Paris: Payot, 1955. 315p.

BOREHAM, M.M.; ROUBIK, D.W. Population change and control of africanized honey bees (Hymenoptera: Apidae). Bulletin of Entomological Society of America, v.33, n. 1, p.34-39, 1987. https://doi.org/10.1093/besa/33.1.34

BOMMARCO, R.; MARINI, L.; VAISSIĖRE, B.E. Insect pollination enhances seed yield, quality, and market value in oilseed rape. Oecologia, v.169, n.4, p.1025-1032, 2012. https://doi. org/10.1007/s00442-012-2271-6

CARVALHO, A.M.C.; BEGO, L.R. Seasonality of dominant species of bees in the Panga Ecological Reserve, Cerrado, Uberlândia, MG. Anais da Sociedade Entomológica do Brasil, v.24, n.2, p.327-329, 1995.

CHAMBÓ, E.D.; OLIVEIRA, T.E.; GARCIA, R.C; DUARTE-JÚNIOR, J.B.; RUVOLO-TAKASUSUKI, M.C.C; TOLEDO, V.A. Pollination of rapeseed (Brassica napus) by africanized honeybees (Hymenoptera: Apidae) on two sowing dates. Anais da Academia Brasileira de Ciências, v.86, n.4, p.2087-2100, 2014. http://dx.doi. org/10.1590/0001-3765201420140134

DEL SARTO, M.C.L.; PERUQUETTI, R.C.; CAMPOS, L.A.O. Evaluation of the neotropical stingless bee Melipona quadrifasciata (Hymenoptera: Apidae) as pollinator of greenhouse tomatoes. Journal of Economic Entomology, v.98, n.2, p.260-266, 2005. https://doi.org/10.1603/0022-0493-98.2.260

DELAPLANE, K.S.; MAYER, D.F. Crop pollination by bees. New York: CABI Publishing, 2000. 352p.
DURÁN, X.A.; ULLOA, R.B.; CARRILLO, J.A.; CONTRERAS, J.L.; BASTIDAS, M.T. Evaluation of yield component traits of honeybeepollinated (Apis mellifera L.) rapeseed canola (Brassica napus L.). Chilean Journal of Agricultural Research, v.70, n.2, p.309314, 2010.

EICKWORT, G.C.A. A comparative morphological study and generic revision of the Augochlorine bees (Hymenoptera: Halictidae). The University of Kansas Science Bulletin, v.48, p.325-524, 1969. https://doi.org/10.5962/bhl.part. 11227

EMPRESA BRASILEIRA DEPESQUISA AGROPECUÁRIA (EMBRAPA). Sistema brasileiro de classificação de solos. Rio de Janeiro: Centro Nacional de Pesquisa de Solos, 2006. 286p.

EMPRESA BRASILEIRA DE PESQUISA AGROPECUÁRIA (EMBRAPA) Definição e histórico da canola. Passo Fundo, Brasil, 2011 . Available from: http://www.cnpt.embrapa.br/culturas/canola/definicao. htm. Access on: Nov. 222018.

FADINI, M.A.M.; SANTA-CECÍLIA, L.V.C. Manejo integrado de pragas do maracujazeiro. Informe Agropecuário, Belo Horizonte, v.21, n.206, p.29-33, 2000.

FREITAS, B.M.; PAXTON, R.J. A comparison of two pollinators: the introduced honey bee (Apis mellifera) and an indigenous bee (Centris tarsata) on cashew (Anacardium occidentale L.) in its native range of NE Brazil. Journal of Applied Ecology, v.35, n. 1, p.109-121, 1998.

GARÓFALO, C.A.; MARTINS, C.F.; AGUIAR, C.M.L.; LAMA, M.A.; SANTOS, I.A. As abelhas solitárias e perspectivas para seu uso na polinização do Brasil. In: IMPERATRIZ-FONSECA, V.L. (Org.). Polinizadores no Brasil: contribuição e perspectivas para a biodiversidade, uso sustentável, conservação e recursos naturais. São Paulo: Edusp, 2012. p.183-202.

GARRATT, M.P.D.; COSTON, D.J.; TRUSLOVE, C.L.; LAPPAGE, M.G.; POLCE, C.; DEAN, R.; BIESMEIJER, J.C.; POTTS, S.G. The identity of crop pollinators helps target conservation for improved ecosystem services. Biological Conservation, v.169, p.128-135, 2014. https://doi.org/10.1016/j. biocon.2013.11.001

GLAGLIANONE, M.C.; CAMPOS, L.A.O. Plano de manejo para os polinizadores do tomateiro. Rio de Janeiro: Funbio, 2015. 48p.

HALINSKI, R.; DORNELES, A.L.; BLOCHTEIN, B. Bee assemblage in habitats associated with Brassica napus L. Revista Brasileira de Entomologia, v.59, n.3, p.222-228, 2015. http://dx.doi. org/10.1016/j.rbe.2015.07.001

HEARD, T.A. The role of stingless bees in crop pollination. Annual Review of Entomology, v.44, n. 1, p.183-206, 1999. https://doi. org/10.1146/annurev.ento.44.1.183

IMPERATRIZ-FONSECA, V.L.; SARAIVA, A.M.; JONG, D. Bees as pollinators in Brazil: assessing the status and suggesting best practices. Ribeirão Preto: Holos Editora, 2006. $112 \mathrm{p}$. 
JAUKER, F.; BONDARENKO, B.; BECKER, H.C.; STEFFAN-DEWENTER, I. Pollination efficiency of wild bees and hoverflies provided to oilseed rape. Agricultural and Forest Entomology, v. 14, n. 1, p.81-87, 2012. https://doi.org/10.1111/j.1461-9563.2011.00541.x

KAMLER, F.; JAŠ, S. Influence of pollination by honeybee on seed yield on selected cultivars of winter rape. Journal of Apicultural Science, v.47, n.2, p.119-125, 2003.

KEARNS, C.A.; INOUYE, D.W.; WASER, N.M. Endangered mutualisms: the conservation of plant-pollinator interactions. Annual Review Ecology, Evolution and System, v.29, p.83-1 12, 1998. https:// doi.org/10.1146/annurev.ecolsys.29.1.83

KEVAN, P.G.; VIANA, B.F. The global decline of pollination services. Tropical Conservation Science, v.4, n.4, p.3-8, 2003. https://doi. org/10.1080/14888386.2003.9712703

KLEIN, A.M.; VAISSIERE, B.E.; CANE, J.H.; STEFFAN-DEWENTER, I.; CUNNINGHAM, S.A.; KREMEN, C.; TSCHARNTKE, T. Importance of pollinators in changing landscapes for world crops. Proceedings of the Royal Society B: Biological Sciences, v.274, n. 1608, p.303313, 2006. https://doi.org/10.1098/rspb.2006.3721

LOPES, M.; FERREIRA, J.B.; SANTOS, G. Abelhas sem-ferrão: a biodiversidade invisível. Agriculturas, v.2, n.4, p.7-9, 2005.

MARGALEF, R. Homage to Evelyn Hutchinson, or why is there an upper limit to diversity. New Haven: Connecticut Academy of Arts and Sciences, 1972. 23p.

MARTINS, C.F. Comunidade de abelhas (Hymenoptera, Apoidea) da caatinga e do cerrado com elementos de campo rupestre do Estado da Bahia, Brasil. Revista Nordestina de Biologia, v.9, p.225-257, 1994.

MICHENER, C.D. The bees of the world. Washington: John Hopkins, 2000. $913 p$.

MORANDIN, L.A.; WINSTON, M.L. Wild bee abundance and seed production in conventional, organic, and genetically modified canola. Ecological Applications, v. 15, n.3, p.871-881, 2005. https://doi.org/10.1890/03-5271

MORANDIN, L.A.; WINSTON, M.L.; ABBOTT, V.A.; FRANKLIN, M.T. Can pastureland increase wild bee abundance in agriculturally intense areas? Basic and Applied Ecology, v.8, n.2, p.1 17-124, 2007. https://doi.org/10.1016/j.baae.2006.06.003

MUNAWAR, M.S.; SARWAR, G.; RAJA, S.; WAGHCHOURE, E.S.; IFTIKHAR, F; MAHMOOD, R. Pollination by honeybee (Apis mellifera) increases seed setting and yield in black seed (Nigella sativa). International Journal of Agriculture and Biology, v. 1 1, n.9, p.61 1-615, 2009.

MUSSURY, R.M.; FERNANDES, W. Studies of the floral biology and reproductive system of Brassica napus L. (Cruciferae). Brazilian Archives of Biology and Technology, v.43, n. 1, p.111-117, 2000. http://dx.doi.org/10.1590/S1516-89132000000100014

NETO, P.L. Levantamento planimétrico $n^{\circ}$ 36.243. Prefeitura de Uberlândia, Uberlândia, Minas Gerais, 2008. (Relatório Técnico).

OLLERTON, J.; WINFREE, R.; TARRANT, S. How many flowering plants are pollinated by animals? Oikos, v.120, n.3, p.321-326, 201 1. http://dx.doi.org/10.1111/j.1600-0706.2010.18644.x
PIRANI, J.R.; CORTOPASSI-LAURINO, M. Flores e abelhas em São Paulo. São Paulo: EDUSP/FAPESP, 1993. 192p.

PIRES, C.S.S.; SILVEIRA, F.A.; CARDOSO, C.F.; OLIVEIRA, G.M.; PEREIRA, F.F.O.; SOUZA, V.V.; NAKASU, E.Y.T.; PAES, J.S.O.; TELES, E.; SILVIE, P.; RODRIGUES, S.; MIRANDA, J., SCOMPARINI, A.; BASTOS, C.; OLIVEIRA, G.S.; OLIVEIRA, J.E.; SANTOS, J.B.; BARROSO, P.A.V.; SUJII, E.; FONTES, E. Visitantes florais em espécies cultivadas e não cultivadas de algodoeiro (Gossypium spp.), em diferentes regiões do Brasil. Brasília: Embrapa Recursos Genéticos e Biotecnologia, 2006. 38p. (Boletim de Pesquisa e Desenvolvimento $n^{\circ} 148$ ).

RAMALHO, M.; IMPERATRIZ-FONSECA, V.L.; GIOVANNINI, A.K. Ecologia nutricional de abelhas sociais. In: PANIZZI, A.R., PARRA, J.R.P. (Org.). Ecologia nutricional de insetos e suas implicações no manejo de pragas. Brasília/Barueri: CNPq/Manole, 1991. p.225-252.

ROSA, A.S.; BLOCHTEIN, B.; LIMA, D.K. Honey bee contribution to canola pollination in Southern Brazil. Scientia Agricola, v.68, n.2, p.255-259, 2011 . http://dx.doi.org/10.1590/ SO103-90162011000200018

ROSA, R.; LIMA, S.C.; ASSUNÇÃO, W.L. Abordagem preliminar das condições climáticas de Uberlândia (MG). Sociedade @ Natuereza, v.3, n.1, p.91-108, 1991.

SABBAHI, R.; OLIVEIRA, D.; MARCEAU, J. Influence of honey bee (Hymenopetra: Apidae) density on the production of canola (Cruciferae: Brassicaceae). Journal Economic Entomology, v.98, n.2, p.367-372, 2005. http://dx.doi. org/10.1603/0022-0493-98.2.367

SANTOS, A.O.R.; BARTELLI, B.F.; NOGUEIRA-FERREIRA, F.H. Potential pollinators of tomato, Lycopersicon esculentum (Solanaceae), in open crops and the effect of a solitary bee in fruit set and quality. Journal Economic Entomology, v.107, n.3, p.987-994, 2014. https://doi.org/10.1603/ EC13378

SANTOS, F.M.; CARVALHO, C.A.L.; SILVA, R.F. Diversidade de abelhas (Hymenoptera: Apoidea) em uma área de transição Cerrado-Amazônia. Acta Amazonica, v.34, n.2 p.31-328, 2004. http://dx.doi.org/10.1590/ So044-59672004000200018

SANTOS, G.M.M.; AGUIAR, C.M.L.; GENINI, J.; MARTINS, C.F.; ZANELLA, F.C.V.; MELLO, M.A.R. Invasive africanized honeybees change the structure of native pollination networks in Brazil. Biological Invasions, v.14, n.11, p.2369-2378, 2012. https:// doi.org/10.1007/s 10530-012-0235-8

SILVEIRA, F.A.; PINHEIRO-MACHADO, C.; SANTOS, I.A.; KLEINERT, A.M.P.; IMPERATRIZ-FONSECA, V.L. Taxonomic constraints for the conservation and sustainable use of wild pollinators - the Brazilian wild bees. In: KEVAN, P.; IMPERATRIZ-FONSERCA, V.L. (Org.). Pollination bees: the conservation link between agriculture and nature. v.2. Brasília: Ministério do Meio Ambiente, 2006. p. 47-56.

SILVEIRA-NETO, S.; NAKANO, O.; BARBIN, D.; VILLA NOVA, N.A. Manual de ecologia de insetos. São Paulo: Agronômica Ceres, 1976. 420p. 
SMITH, W. Honey bees on canola. Orange, New South Wales: New South Wales Agriculture, Department of Primary Industries, 2002. Available from: http://www.dpi.nsw.gov.au/_data/ assets/pdf_file/0013/117112/bee-on-canoloa.pdf. Access on: Aug. 152017.

TAURA, H.M.; LAROCA, S. A associação de abelhas silvestres de um biótopo urbano de Curitiba (Brasil), com comparações espaço-temporais: abundância relativa, fenologia, diversidade e exploração de recursos (Hymenoptera, Apoidea). Acta Biológica Paranaense, v.30, p.35-137, 2001. http://dx.doi.org/10.5380/ abpr.v30i0.599

TOMM, G.O.; FERREIRA, P.E.P.; AGUIAR, J.L.P.; CASTRO, A.M.G.; LIMA, S.M.V.; DE MORI, C. Panorama atual e indicações para aumento de eficiência da produção de canola no Brasil. Passo Fundo: Embrapa Trigo, 2009. Available from: http://www.cnpt. embrapa.br/biblio/do/p_do 1 18.htm. Access on: Aug. 182017.

VELTHUIS, H.H.W.; VAN DOORN, A. A century of advances in bumblebee domestication and the economic and environmental aspects of its commercialization for pollination. Apidologie, v.37, p.421-451, 2006. https://doi.org/10.1051/apido:2006019
VIEIRA, C.U.; RODOVALHO, C.M.; ALMEIDA, L.O.; SILVA, A.C.S.; BONETTI, A.M. Interaction between Trigona spinipes Fabricius, 1793 (Hymenoptera: Apidae) and Aethalion reticulatum Linnaeus, 1767 (Hemiptera: Aethalionidae) in Mangifera indica (Anacardiaceae). Bioscience Journal, v.23, n. 1, p.10-13, 2007.

WILMS, W.; IMPERATRIZ FONSECA, V.L.; ENGELS, W. Resource partitioning between highly eusocial bees and possible impact of the introduced Africanized honey bee on native stingless bees in the Brazilian Atlantic Rainforest. Studies on Neotropical Fauna and Environment, v.31, n.3-4, p.137-151, 1996. https://doi. org/10.1076/snfe.31.3.137.13336

WITTER, S.; BLOCHTEIN, B.; NUNES-SILVA, P.; TIRELLI, F.P.; LISBOA, B.B.; BREMM, C.; LANZER R. The bee community and its relationship to canola seed production in homogeneous agricultural areas. Journal of Pollination Ecology, v.12, n.3, p.1521, 2014. http://dx.doi.org/10.26786/1920-7603(2014)9

WITTER, S.; TIRELLI, F. Polinizadores nativos presentes em lavouras de canola no Rio Grande do Sul. In: WITTER, S.; NUNES-SILVA, P.; BLOCHTEIN, B. (Org.). Abelhas na polinização de canola - benefícios ambientais e econômicos. Porto Alegre: EDIPUCRS, 2014. p.29-36. 